Craig Smith

University of Glasgow, Scotland

ORCID: 0000-0002-6707-5977

e-mail: Craig.Smith@glasgow.ac.uk

\title{
Adam Smith on Philosophy and Religion
}

DOI: http://dx.doi.org/10.12775/RF.2018.025

"Gross sophistry has scarce ever had any influence upon the opinions of mankind, except in matters of philosophy and speculation; and in these it has frequently had the greatest." (WN V.i.f: 769).

Moral philosophers seem, finally, to have re-discovered the work of Adam Smith and have begun to take more seriously the approach to moral philosophy that is to be found in his Theory of Moral Sentiments (1759) [TMS]. Smith's book was widely read and highly influential during his lifetime, but passed out of fashion in the centuries after his death. One reason for this was that it fell between two divergent trends in the development of moral philosophy. As normative moral philosophy, that part of the discipline concerned with providing us with reasons to act in a particular manner, and empirical moral psychology, that part of the discipline interested in how we think about morality, became distinct fields of intellectual inquiry, Smith's Theory, with its focus on observation and explanation of how humans experience moral judgement, was of limited interest to those philosophers whose attention was directed towards the prescriptive identification of how people ought to think about morality (Campbell 2013).

This tension was apparent during Smith's lifetime. Smith's great friend David Hume distinguished between moral philosophy conducted by an 'anatomist' or a 'painter' (Hume 1976: 620-21). What Hume meant was that his approach was an anatomical, analytical inquiry that sought to dissect the phenomenon of moral judgement. He was chiefly concerned with explaining morality rather than in providing arguments in favour of any particular proposition in morals. The other approach, that 
of the 'painter', was the approach of Hume and Smith's immediate predecessor in the Scottish Enlightenment, Francis Hutcheson. Hutcheson, and those influenced by him, such as Adam Ferguson, saw the role of the professor of moral philosophy to be primarily one of inculcating young students in the principles of how they ought to act. By depicting morally correct behaviour in noble colours and morally dubious behaviour in an unfavourable light, the 'painters' saw themselves as moralists whose philosophy was part of the campaign to elicit good behaviour. Hume's position was that in order to be able to educate individuals in the correct moral attitudes we must first have a sound awareness of human nature and the nature of moral judgement. Thus the anatomist can advise the painter. But the painter should not seek to mix his advocacy with anatomising, for the simple reason that he will inevitably seek to understand individuals as they ought to be rather than as they are (Hume 1976: 621).

In this paper I want to explore some of the implications of Smith's understanding of the role of philosophy in the light of this observation on the two aspects of philosophy that I believe he shared with Hume. Smith, I will argue, was concerned about the danger that devotion to philosophical principle might be bought at the expense of attention to evidence, and that this danger in speculation required an anatomical 'reality check' be applied to philosophy. I want to do so with particular reference to what he says about the relationship between philosophy and religion. There is an ongoing debate in the scholarship about the religious passages in TMS: some see them as purely naturalistic and descriptive (Haakonssen 1981: 77; Rothschild 2001; Fleischacker 2003: 138-42; Phillipson 2010; Kennedy 2013) or naturalistic and socially beneficial (Lazaro 2016); others have taken them seriously as substantive religious commitments (Macfie 1967: 116), and indeed evidence that Smith is providing arguments for the existence of God (Oslington 2011; Long 2011); still others argue that his moral philosophy depends in crucial ways on the assumption that God exists (Kleer 1995; Hill 2001; Otteson 2002; Graham 2016). ${ }^{1}$ Much has been written over the last few years from each of these perspectives, but the focus in this discussion has always been on reading the passages where Smith discusses religious themes in an attempt to understand his views on religion. My basic position on this is to adopt a view on the terrain charted by Hanley (2015), Schwarze and Scott (2015), and Heydt (2017). Such a position

1 A more sophisticated position is taken by Maria Carrasco, who argues that Smith's writings on religion are simultaneously explanatory and normative. One might conclude from this, though Carrasco does not, that the success of his descriptive account of religious sentiments is itself an argument for belief in God in the sense that it is 'natural' (Carrasco 2016: 218). 
takes the view that Smith provides an essentially naturalised argument about religious belief. In such a reading Smith seeks to account for the naturalness and ubiquity of religious beliefs, without committing (or having to commit) himself to any view on the truth of such beliefs. To quote Heydt (2017: 80) Smith gives us a 'psychological genealogy of belief in a designer' without providing an argument as to whether we should believe in a designer.

But my interest here is something different: it is, if you like, the opposite. Rather than asking what Smith's arguments tell us about his views on religion, I want instead to ask - what do the passages on religion tell us about Smith's understanding of philosophy? This approach accepts that religion and religious sentiment are part of human experience - the spiritual is real for Smith and as a result must be explained and related to other elements of human experience such as morality. On the other hand, because Smith's Theory is empirically grounded, he is able to provide an account of why people relate religious arguments to moral arguments. ${ }^{2}$ For Smith it is enough to be able to say that people do, in fact, believe the sort of things he describes in the sort of way that he describes.

What animates this paper is my attempt to address a series of unflattering comments that Smith makes about philosophy and philosophers. These remarks are peppered throughout The Theory of Moral Sentiments. Through the early chapters he makes a number of suggestions that indicate doubts about the place of philosophy in human life. For example in (TMS I.i.4.6: 21) there is an extended discussion over the fact that philosophical differences are less animating to us than absence of fellow-feeling, and shortly afterwards he describes how it is the society of everyday life rather than philosophy that soothes the mind (TMS I.i.4.10: 23), while later still he observes that philosophers are bad company as they are too preoccupied by their own studies (TMS I.ii.2.6: 34). But perhaps most interesting for our purposes are his comments (TMS I.i.3.3: 17) that his examples are chosen from everyday life precisely to

2 For the purposes of this paper I am bracketing the many mentions of providence in Smith's work. My view on these passages is that they rarely carry explanatory weight for Smith and are, in most cases, little more than stylistic ornaments - as Gavin Kennedy would have it they are 'a rhetorical, not a theological device' (Kennedy 2013: 479). I do not, however, see this purely in the light of Smith's religious views. Instead I regard his relative disinterest in providence as a feature of his almost total disinterest in metaphysics. As a result, those critics who see a vital role of God in explaining the origin of the naturalistic traits that Smith describes are, in my view, mistaken as Smith remains at best neutral, and at worst dismissive of such concerns. What Smith does do in TMS is provide us with an account of why humans believe in providence and heaven that depends solely on the moral sentiments. See below for details of this. 
avoid our view of them being perverted by 'wrong systems,' that we can be misled by a 'refinement of philosophy' (TMS VII.ii.1.34: 287), and that we can overestimate the role of reason in our behaviour (TMS II.ii.3.5: 87). These arguments seem to culminate in the famous passage on the man of system, where Smith charts the political consequences of an excessive commitment to philosophical system (TMS VI.ii.2.17: 233-4).

\section{The Essays on Philosophical Subjects}

What is particularly interesting about Smith's account of the principles that lead and direct philosophy is that he grounds them firmly in the sentiments. The urge to pursue systematic knowledge, understood as structured, organised and comprehensive knowledge, is a product of a human need for emotional stability. This in turn prompts the exercise of the imagination to account for phenomena in a way that banishes emotional unease. Smith's analysis begins in the History of Astronomy with three emotions: wonder, surprise and admiration. We wonder at things we have not seen before, we are surprised when familiar objects appear out of their usual setting and we admire an explanatory account that renders these familiar to us. By stressing the emotional origins of philosophical enquiry Smith is not rejecting the view that knowledge can be useful. But what he is doing is stating that usefulness is not the original motive to enquiry (Astronomy III.5: 51). Instead our thirst for knowledge comes from a far more basic part of our shared human psychology. It arises from the fact that humans have emotional responses to the world around them and that they operate with a form of associationist psychology. Smith, largely following Hume, believes that our imagination develops habitual patterns of thought that we use to orientate our lives through the association of ideas drawn from experience. Wonder and surprise arise when these habitual expectations are confronted with a completely new phenomenon or with an irregularity in the usual appearance of familiar events.

Surprises make us uneasy as they interrupt the smooth operation of the imagination and it is this uneasiness that prompts us to seek explanation. Explanation is achieved when we are able to account for the surprising event in terms that are familiar to our imagination from past experience. Once we have become accustomed to an initially surprising occurrence we are left with a residual uneasiness if we are not able to provide a satisfactory account of the phenomenon. We wonder at the cause of a phenomenon and seek to classify it in terms of our own experience. Once we have successfully placed a phenomenon our minds are able to operate smoothly and are freed from unease. We come to admire the account of the phenomenon that we have developed to the 
extent that it is familiar to us and 'beautiful' ${ }^{3}$ At this stage the process that Smith is describing is a general account of human epistemic urges. According to Smith, the pursuit of philosophy is understood as 'the science of the connecting principles of nature' (Astronomy II.2: 45). The philosopher is engaged in a process of 'rendering familiar to the imagination' (Astronomy IV.65: 96) chains of events that appear, initially at least, to be chaotic. The philosopher methodises human experience by illustrating the chains that connect phenomena. The result is the reduction of surprise, the satisfaction of wonder and the elucidation of admiration.

The approach is summarized by Smith in the following terms:

Philosophy, by representing the invisible chains which bind together all these disjointed objects, endeavours to introduce order into this chaos of jarring and discordant appearances, to allay this tumult of the imagination, and to restore it, when it surveys the great revolutions of the universe, to that tone of tranquillity and composure, which is both most agreeable in itself, and most suitable to its nature. (Astronomy II. 12: 46)

The philosopher becomes an active inquirer into the connections that lie behind phenomena. He undertakes in a self-conscious fashion the general model of human epistemic experience that Smith outlines.

Smith begins Section III of the Astronomy with a significant initial foray. Rather than plunge straight into the astronomical systems that held from ancient times Smith begins with an account of polytheistic religion. What is startling about this is that he is accounting for primitive religion with the same psychological model that he will later apply to philosophy. Polytheism is the 'natural' response of an ignorant people to events that are beyond their everyday experience. Unexpected events are attributed to the intervention of particular deities who disrupt the regular pattern of events. These deities are then understood as operating with anthropomorphic characters and a superhuman intelligence that allows them deliberately to bring about the apparently chaotic events of nature to satisfy their whims. Polytheistic religion, like philosophy, operates from the same general epistemic motivators of surprise and wonder coupled with an associationist psychology.

On Smith's account we should expect the polytheistic superstitions of savage societies to gradually give way to monotheistic religions which understand God as a final cause of a regular universe (Ancient Physics 9: 114). This enterprise takes place at the same time as the development of modern philosophy: Smith identifies two principles that he uses

3 The stress on the beauty of explanations has led some to view Smith's account as an aesthetics of science. See Thomson (1965). 
to account for the gradual evolution of our thinking about astronomy. The first of these is gap-plugging. A system of explanation will successfully convince us to the extent it is able to lead the imagination smoothly through its account of the phenomena at hand. If it fails to account for a part of the observed phenomena the mind will 'feel' the gap and fail to be convinced. The second principle is that of explanatory simplicity. If convincingness depends on the ease with which the mind is led through the account of the phenomena at hand, then the system which is able to do this in the simplest fashion will be more satisfactory to our imaginations.

Theoretical beauty is a product of coherence (gaplessness) and parsimony and both of these are assessed in the light of observation of the phenomena concerned. One system of astronomy will come to replace another when it is able to explain everything (and more) than the prior system could explain without resorting to a complexity that will fail to lead the mind smoothly through the explanatory process.

This leads Smith to the history of astronomy. If our admiration of a philosophical account depends upon its ability to banish surprise and satisfy wonder then explanations will compete with each other in terms of their ability to satisfy the desire for calmness of mind in the light of observed phenomena. What Smith proceeds to do in the remainder of the Astronomy and in the subsequent two essays is to examine the development and succession of various systems of philosophy. A system is an 'imaginary machine invented to connect together in the fancy those different movements and effects which are already in reality performed.' (Astronomy IV. 19: 66). The acceptance of a system of philosophy depends upon its ability to calm our minds, and to explain the phenomena in question in a fashion that both leads the imagination in a smooth and gap free fashion, and does so in a more elegant and coherent fashion than alternative accounts.

The account of systematic thought that Smith provides in the Astronomy, driven as it is by the emotional reaction to Wonder and the prompt of 'uncertainty and anxious curiosity' (Astronomy II.4: 40), provides us with a notion, not just of what makes a coherent system in philosophy, but what conditions are necessary for a successfully functioning human mind. The 'pusillanimous superstition' (Astronomy III.2: 50) of polytheism is replaced by philosophy. But that philosophy is only successful so long as it is able to fulfil the same function of psychological calming as its predecessor. Smith illustrates this by asking us to imagine a person raised in the regular nature of our world who is transported to another world where the laws of nature are different (Astronomy II.10: 43), the result, he argues, would be madness - the complete disordering of that person's mental cartography. Philosophy for Smith is a 'methodize[d]' (Astronomy IV.15: 64) version of our mental order, but it is also prone 
to an ambitious over-reach, to extend its explanatory range to cover as much as possible in one system.

Smith's account is driven by a psychological need to explain the world. This urge is so powerful that it drives us to attempt to systematise before we have sufficient knowledge. As he puts it: 'This natural anticipation, too, was still more confirmed by such a slight and inaccurate analysis of things, as could be expected in the infancy of science, when the curiosity of mankind, grasping at an account of all things before it had got full satisfaction with regard to any one, hurried on to build, in imagination, the immense fabric of the universe.' (Ancient Physics 3: 107-8). The devotion to such systems of thought is like the devotion to a system of religious belief. It's adherents cling to it, they seek to defend it against its critics, to suppress new ideas which challenge it, and to extend its application to increasingly wide fields. This, I want to argue is an abiding concern for Adam Smith. He is willing to see that philosophy and religion have their origins in the same features of human psychology, but he is also willing to see that those drivers of belief can open up the same flaws in philosophers as they open up in the religious. Devotion to system can become just as much a vice as religious superstition or enthusiasm. To slightly abuse a comment that Smith makes with reference to Copernicus: '... how easily the learned give up the evidence of their senses to preserve the coherence of the ideas of their imagination...' (Astronomy IV.35: 77)

\section{Smith's Method}

My argument, then, is that Smith's philosophical methodology is developed in response to this worry. His empiricism stresses that systems must be able to account for all of the observable features of the relevant phenomenon. We see a clear application of this in TMS. There Smith sets himself the 'anatomical' task of examining extant systems of moral philosophy and contrasting them with his own system. What makes his approach so interesting is that it is based on an examination of the failure of other systems to provide an adequate account of the experience of moral judgement. What this means is that these systems - those based on selfishness, benevolence, reason and the classical virtues - fail in some important respects to capture the actual experience of moral judgement. Working from this starting point Smith attempts to build an alternative account that better captures the actual experience of moral judgement. Thus the failings of the more prescriptive moralists lay not so much in their conclusions as in the faulty methodology that they applied to reach them. 
One obvious example of this is Smith's discussion of the place of motive in our moral judgement. If we adopt a moral philosophy that focuses on the benign or malign consequences of our actions (such as utilitarianism) we miss out on a significant part of moral judgement, that part that assesses the motivations of actors. As a result a purely consequentialist moral philosophy will have trouble encompassing assessments of the worthiness of individuals in terms of character and motivation.

Smith's project, like that of Hume before him, is based on the view that a successful theory of what we ought to do (a normative theory) must be based on an accurate understanding of human moral psychology. A 'rational' system that provides an argument in favour of a particular normative position will fail if that argument is based on a partial understanding of how our moral thought process actually operates. Chief among the failings of the existing systems of moral philosophy that Smith engaged with was that they elevated a concern for principle and a desire to provide an account of how we ought to think about morality above a concern for how moral judgement actually takes place. As Smith puts it in his discussion of the philosopher Epicurus: 'Epicurus indulged a propensity, which is natural to all men, but which philosophers in particular are apt to cultivate with a peculiar fondness, as the great means of displaying their ingenuity, the propensity to account for all appearances from as few principles as possible.' (TMS VII.ii.2.14: 299). Now this approach is not a vice in the field of explanation. So long as an empirical study of how human beings actually make moral judgements bases its generalisations on the evidence, the idea of seeking the simplest principle behind such judgements is sound.

The failure of previous Schools of philosophy is that they provide philosophically sophisticated arguments about what the content of moral judgements ought to be that are divorced from how actual agents make moral decisions. Moral philosophy tends to be separated from actual moral experience. Smith's strategy to highlight this disconnect between normative moral philosophy and actual moral experience is to show that these principle-based accounts issue in counterintuitive prescriptions and strained reasoning and that this is, in Smith's view, evidence that they provide only a partial examination of moral judgement. Each school, in Smith's view, is subject to a kind of tunnel vision. That is to say that the focus on one right way of thinking about morality, or upon one principle that is supposed to issue in authoritative answers between competing moral views, means that these philosophers are unable to provide an account that captures the true complexity and subtlety of moral judgement. For example, Smith's discussion of authors who base morality on self-love shows how they are forced to adopt unconvincing positions to reconcile their account with the reality of the experience of sympathy and fellow feeling. Such thinkers are forced to try to reduce 
our concern for others to a calculation of interest rather than accepting it as a feature of moral experience that must be encompassed with a moral theory on its own terms. Similarly, the Stoic system is dismissed as incapable of overcoming the reality of the passions it seeks to suppress. As Smith puts it: 'The reasonings of philosophy, it may be said, though they may confound and perplex the understanding, can never break down the necessary connection which Nature has established between causes and their effects.' (TMS VII.ii.1.47: 293). It is here that we see Smith applying his 'reality check' for philosophy.

Several recent studies have sought to interpret this feature of Smith's approach as a version of modern eclecticism, in the sense that he borrows and combines from past traditions (Garrett \& Hanley 2015) in the light of what he discovers from observation. The test of the validity of the schools is that their ideas explain actual moral judgement in a smooth and gapless fashion. Philosophers who attempt to fit reality to their system are bad philosophers in Smith's view. ${ }^{4}$ To say that Smith is an eclectic then gets us part of the way to the position that I have been outlining here. Smith is an eclectic in his attitude to the ancient schools, but more than that, he is a thinker who regards moral experience as by its very nature eclectic. What I mean by this is that Smith's observational method led him to the view that there may very well be elements of our moral experience that do not cohere.

The superiority of Smith's account, in Parts I-V of TMS is that it does precisely that: it looks at different elements of moral experience and attempts to assign them to their proper place in the structure of moral psychology. Each of the potential candidates for a central moral principle - concern for others, self-interest, reason, happiness (utility) and justice (rules) - are discussed in turn as part of an overall account of morality rather than as definitive of the whole of morality. An accurate account of the moral psychology of actual agents addressing concrete examples and struggling to choose the 'right' course of action demonstrates that a number of different principles are at work in our thinking about morality. Smith brings these together in a theory that sees moral judgement as driven by our feelings and achieved through imaginative reflection. The approach concentrates on describing how this struggle is undertaken.

At the very start of the book Smith nails his colours to the mast by rejecting the binary systems that reduce morality to selfishness or benevolence. 'How selfish soever man may be supposed, there are evidently some principles in his nature, which interest him in the fortune of others,

4 This is not a new reading of Smith. James Farrier takes this view of Smith as long ago as 1881, so long as by eclectic we understand not mere combination of ideas from the schools, but also 'a discriminate selection of the elements of truth to be found in them severally' (Reeder 1997: 217). 
and render their happiness necessary to him, though he derives nothing from it except the pleasure of seeing it.' (TMS I.i.1: 9). Simple observation of how people actually behave and think about morality demonstrates that both of these principles must form a part of an accurate moral theory. Human beings are at times benevolent and are at times self-interested, and similarly they at times regard self-interestedness as the 'correct' principle upon which to make decisions, while at other they clearly regard it as correct to act in a benevolent fashion.

Philosophical systems that attempt to reduce morality to either one of these principles will inevitably issue in counterintuitive outcomes when the appropriate motivation or decision principle lies in the other. These systems will then have to invoke convoluted argumentation to preserve their desired principle's relevance. Smith wants to provide us with an account that is able to deal with the issues that this raises in as parsimonious a fashion as possible. The success of his theory will be determined by the extent to which it is both true to our moral experience, and more accurate and theoretically elegant than that of other systems of moral philosophy. Previous philosophers worked with a 'partial and imperfect view of nature' (TMS VII.i.1: 265) leading them to develop a partial understanding of moral experience. That a philosophical position is 'unnatural' becomes Smith's test principle for sound philosophy. In relation to the moral sentiments this suggests that the fact that we do in fact make important connections between religion and morality means that a theory that cannot provide a satisfactory account of that relation will possess a glaring 'gap' and strike us as unconvincing. For the purposes of our present discussion I want to highlight a crucial feature of Smith's commitment to moral sentimentalism: sentiments can come into conflict, the thought processes that arise in reaction to our different sentiments need not cohere, and moral philosophy can be prone to jumping after systems to lay our mind at ease when this occurs. ${ }^{5}$

5 In an interesting aside Smith notes that there is a distinction between moral and natural philosophy in this connection. Discussing Mandeville, he argues that his view must, in some respect, have bordered on the truth, while the system of Des Cartes in natural philosophy could be maintained even though it turned out to have 'no foundation in nature, nor any sort of resemblance to the truth' (TMS VII.ii.4.14: 313), the reason Smith believes this to be the case is that all of us have a personal experience of the act of moral judgement and so are immediately aware of the insufficiency of Mandeville's account as an explanation of something that is familiar to us (TMS VII. ii.4.14: 314). 


\section{Conflicting Sentiments and Conflicting Thought Processes}

Part of the animus for Smith's account of justice in TMS is to distance himself from the argument of his friend David Hume (Raphael 1972/3). Hume's account of justice is, in Smith's view, too dependent on utility. For Smith utility is 'plainly an after-thought' (TMS I.i.4.4: 20; Rosen 2000). Utility based accounts of the social phenomenon of Justice cannot provide an adequate account of the psychology of making judgements about the justice of particular acts of punishment: indeed Hume himself is forced to add a gradually developed 'sympathy' with the public (Hume 1976: 499-500) to his account to render it plausible as an account of the actual experience of justice (TMS II.ii.3.8-10: 89-90). Smith agrees with Hume on the public utility of a system of justice, indeed this forms a core part of his focus on the special status of justice as necessary for social life, but Smith's more sophisticated psychology stresses that utility and justice are distinct. Justice cannot be resolved into utility, and this leaves Smith with the task of distinguishing between the two. ${ }^{6}$

Raphael (1972/3, pp. 96-97) points out that in the example of the centinel that appears in TMS and The Lectures on Jurisprudence, Smith appears to grant Hume too much by stating that the execution of a centinel who falls asleep on duty is just. ${ }^{7}$ If Smith were consistently applying his theory, argues Raphael, he would actually say that the execution is unjust, but may be warranted on grounds of expediency. However, if we examine this passage we find that Smith explicitly invokes distinct languages of justice and utility. He illustrates the point by noting that a 'man of humanity ... must make an effort, and exert his whole firmness and resolution' (TMS II.ii.3.11: 90) to apply the death penalty in the case of the centinel while this difficulty is not present in the case of applying the death penalty for murder. Smith's explanation of the distinction is that:

The very different sentiments with which the spectator views those different punishments, is a proof that his approbation of the one is far from being founded upon the same principles with that of the other. (TMS II.ii.3.11: 91)

6 T. D. Campbell (1971) approaches this issue by arguing that Smith was a 'contemplative utilitarian' who used utility as a principle in philosophical inquiry rather than in his description of actual moral judgements.

7 See also Witzum and Young (2010) and a critical riposte in Vivenza (2010). 
In Smith's own account the long term utility of punishing the Centinel involves different sentiments and a different thought process to that involved in punishing the murderer. The centinel example demonstrates that there may be occasions where the demands of distinct moral sentiments that produce distinct moral judgemental processes can come into conflict. Smith accepts the reality that in sacrificing justice to utility we are in effect abandoning the idea of a unified system of moral philosophy under a single principle of utility, though Smith's theory is able to mitigate this by the central role in regulating judgement that he gives to the impartial spectator. ${ }^{8}$

The discussion of the centinel example ends with a passage where Smith discusses how we deal with difficult situations like this by finding consolation in the belief that the person who suffers as a result will not be punished by 'The justice of God' (TMS II.ii.3.12: 91) in heaven. This passage is one of the most controversial in the debate about Smith's attitude to religion. The orthodox Christian 'atonement' passage was largely removed from the final edition of TMS and replaced by a more generic passage about the ubiquity of beliefs in heavenly justice. Some, like Gavin Kennedy (2013), see this as evidence of a declining religiosity in Smith's work. However, if we take these changes along with the changes in terms of additions that Smith makes to the following chapter on Fortune (TMS II.iii.3.4:107; Schliesser 2013) what we instead see is Smith producing a more coherent and naturalistic account of the origins and function of religious sentiments.

As we discussed above Smith is attempting to account for elements of moral experience, and, to the extent that this is a genuine and widespread experience, he needs to trace its origin in our sentiments and explain its relation to other elements of moral experience. Again - the argument is not evidence for the existence of God, it is an observable phenomenon that must be explained and integrated into our system of thought.

In Smith's account human jurisprudence limits itself to the actions which embody intent instead of seeking to punish the affections of the heart that we view as the actual source of disapproval. Judgement of sentiments is left to 'the great Judge of hearts beyond the limits of every human jurisdiction' (TMS II.iii.3.2: 105). Smith dresses up this discussion by referring to God, Nature, Providence and so forth. But we should be careful to realise what role is being played by God in the explanation

8 One of the ways in which Smith attempts to deal with these distinct modes of thought is through his use of a distinction between justice and police. It is no accident that Smith uses the final pages of TMS to revisit the justice/police distinction and relates it to the subject matter of the proposed third volume on government. Smith took the distinction seriously and clearly saw it as conceptually useful. 
here. Smith has shown us that the irregularity is real, he has described to us what effect it has, and he has shown how that effect can be beneficial. Each of these explanations is fully naturalistic and so mention of providential design here does not invoke an active role for the Deity. In many respects that is the project of Part III, where Smith explains how the operation of the impartial spectator, provides an internalised court which can judge our own behaviour and confirm to us that we have acted with propriety even when actual spectators disapprove of us.

Even here, though, we are faced with situations where good or ill fortune might be experienced beyond the control of the individual and with no apparent other agent responsible. It is here that Smith's notion of heavenly justice comes into its own. Smith has explained to us where this desire comes from: the hope is that outcomes impacted by fortune will be corrected when we come before the ultimate judge. We want things to be different, but it is fortune that gets in the way. This leads us to seek to match outcomes to our preferred judgement of what they ought to be:

he is by no means able to render the fortune of either quite suitable to his own sentiments and wishes. The natural course of things cannot be entirely controlled by the impotent endeavours of man: the current is too rapid and too strong for him to stop it; and though the rules which direct it appear to have been established for the wisest and best purposes, they sometimes produce effects which shock all his natural sentiments. (TMS III.5.9: 168)

A perfect match between our assessments of moral deservingness and outcomes is unattainable by human beings. But the belief that such a thing may be possible is part of our psychological coping mechanism. It is one of the ways in which our minds calm themselves and reconcile us to our fate. Or as Smith would have it:

That there is a world to come, where exact justice will be done to every man, where every man will be ranked with those who, in the moral and intellectual qualities, are really his equals" is "so comfortable to the weakness, so flattering to the grandeur of human nature, that the virtuous man who has the misfortune to doubt of it, cannot possibly avoid wishing most earnestly and anxiously to believe it. (TMS III.2.33: 132)

This is a 'hope and expectation deeply rooted in human nature.' (TMS III.2.33: 132), one which is 'impressed by nature' and later confirmed by philosophy (TMS III.5.3: 163). It has always been connected to moral judgement: 'That the terrors of religion should thus enforce the natural sense of duty, was of too much importance to the happiness of mankind, for nature to leave it dependent upon the slowness and uncertainty of philosophical researches.' (TMS III.5.4: 164). 
For Smith the notion that humanity will ever be able to provide the perfect response to every incidence of fortune is for the next life. His theory accepts that elements of our moral experience will come into conflict, that we will have to live with the fact that fortune intervenes, or that sleeping centinels must be punished, and what Smith's theory does provide us with is a naturalistic account of the emergence of various parts of our moral psychology that assist us in dealing with this fact. If fortune is ineliminable from human life, then what is left for the moral philosopher is the task of understanding how we, ordinary people, come to cope with that fact about the human condition.

\section{Conclusion}

In this paper I have been trying to make the case that Smith's realisation of the intimate sentimental relationship between philosophy and religion runs deeper that we might initially have thought. We may be tempted to take Smith's distinction between superstition and science as the point of divergence between the two: but I have been trying to show that this is not the case. Instead Smith retains a worry that the rush to explain the unknown that religion represents is a permanent feature of philosophy. His description of the schools in astronomy is easily transferable to a discussion of religious sects; his account of the commitment to system, even in the face of mounting evidence, portrays the philosopher as every bit as prone to zealotry as the religious believer.

My aim here has not been to suggest that Smith thought that religious and philosophical belief were equally valuable in epistemic terms. Instead I hope that, by exploring what Smith says about religion and philosophy we find that the 'natural', the everyday, and the familiar play a crucial regulatory role on belief systems.

One reason that I have pursued this thought is because I think it helps us gain traction on what Smith thought we could expect from philosophy. His discussions of the naturalness of a belief in heaven, and the psychological role it plays in allowing us to reconcile ourselves to the reality of the world whilst calming our imaginations, point, in my view, to a problem that Smith saw with our thinking about morality. He obviously thought that humans were imperfect, that they sought the good, but often fell short of this, while at the same time he maintained the possibility of improved (if not total) knowledge of moral ideals. The problem is that as a moral sentimentalist, committed to an accurate anatomy of moral emotion and the disparate thought processes and ideals that it generates, he is forced to admit that our moral sentiments can come into conflict. Smith's answer to the problem was to suggest that the impartial spectator would provide the best guide available to imperfect 
humans as to how to navigate the sort of moral dilemmas that would emerge and to deal with them within the context in which they arose. This sort of reflective behaviour is very different from the philosopher's desire to reduce things to a single principle. Divine justice may be able to reconcile the apparently irreconcilable, and the idea that it might is comforting to us, and allows our imaginations a degree of calm, when we face difficult decisions in cases like the Centinel.

The emotional drive for a totalising moral system sees its earliest expression in polytheistic explanation, but as Smith's discussion of justice and the naturalness of religious belief in response to the impact of fortune shows us, it is a desire still present in us today and one which is so strong that it can mislead our theories. Smith's method constantly returns to everyday examples, and this is not just a rhetorical strategy to illustrate his points - it is a 'reality check' to keep his method grounded in the phenomena that it must explain in order to succeed.

\section{Bibliography}

Campbell, Tom. D. (1971) Adam Smith's Science of Morals (London: Routledge).

Carrasco, Maria A. (2016) 'The Role of God in Adam Smith's Theory of Moral Sentiments: Necessity or Convenience?' in R. Lazaro \& J. Seoane (eds.) The Changing Faces of Religion in XVIII-th Century Scotland, Religion and Civil Society, Series Vol. 7, Hildesheim: Georg Olms, pp. 206-25.

Fleischacker, Samuel (2003) On Adam Smith's Wealth of Nations: A Philosophical Companion (Princeton: Princeton University Press).

Garret, Aaron \& Hanley, Ryan Patrick (2015) 'Adam Smith: History and Impartiality' in A. Garret \& J.A. Harris (eds.) Scottish Philosophy in the Eighteenth Century, Vol. 1: Morals, Politics, Art, Religion, Oxford: Oxford University Press, pp. 239-282.

Graham, Gordon (2016) 'Adam Smith and Religion' in R.P. Hanley (ed.) Adam Smith: His Life, Thought, and Legacy, Princeton: Princeton University Press, pp. 305-20.

Haakonssen, Knud (1981) The Science of a Legislator (Cambridge: Cambridge University Press).

Hanley, Ryan Patrick (2015) 'Adam Smith on the "Natural Principles of Religion"', Journal of Scottish Philosophy, 13.1, pp. 37-53.

Heydt, Colin (2017) 'The Problem of Natural Religion in Smith's Moral Thought' Journal of the History of Ideas, Vol. 78, no. 1, pp. 73-94.

Hill, Lisa (2001) 'The Hidden Theology of Adam Smith' European Journal of the History of Economic Thought, Vol. 8, no. 1, pp. 1-29.

Hume, David (1976) A Treatise of Human Nature, ed. L.A. Selby-Bigge, rev. P.H. Nidditch (Oxford: Clarendon). 
Kennedy, Gavin (2013) 'Adam Smith on Religion' in C.J. Berry, M.P. Paganelli \& C. Smith (eds.) The Oxford Handbook of Adam Smith, Oxford: Oxford University Press, pp. 464-84).

Kleer, Richard (1995) 'Final Causes in Adam Smith's Theory of Moral Sentiments' Journal of the History of Philosophy, Vol. 33, no. 2, pp. 275-300.

Lazaro, Raquel (2016) 'The Existence of God and the Role of Religion according to Adam Smith', in R. Lazaro \& J. Seoane (eds.) The Changing Faces of Religion in XVIIIth Century Scotland, Religion and Civil Society Series Vol. 7, Hildesheim: Georg Olms, pp. 145-169.

Long, Brendan (2011) 'Adam Smith's Theodicy', in P. Oslington (ed.) Adam Smith as Theologian, London: Routledge, pp. 98-105.

Macfie, Alexander Lyon (1967) The Individual in Society: Papers on Adam Smith, Glasgow: George Allen and Unwin.

Oslington, Paul (2011) 'Introduction: Theological readings of Adam Smith' in P. Oslington (ed.) Adam Smith as Theologian, London: Routledge, pp. 1-16.

Otteson, James (2002) Adam Smith's Marketplace of Life, Cambridge, Cambridge University Press.

Phillipson, Nicholas (2010). Adam Smith: an enlightened life, London: Allen Lane.

Raphael, Daiches D. (1972-1973). 'Hume and Adam Smith on Justice and Utility.' Proceedings of the Aristotlean Society, New Series, Vol. 73: 87-103.

Raphael, Daiches D. (2007). The Impartial Spectator: Adam Smith's Moral Philosophy (Oxford: Clarendon).

Reeder, John (1997) On Moral Sentiments: contemporary responses to Adam Smith, Bristol Thoemmes.

Rosen, F. (2000). 'The Idea of Utility in Adam Smith's The Theory of Moral Sentiments.' History of European Ideas, 26: 79-103.

Rothschild, Emma (2001). Economic Sentiments: Adam Smith, Condorcet, and the Enlightenment, Cambridge Mass.: Harvard University Press.

Schliesser, Eric (2013).'The Piacular; or, seeing oneself as a Moral Cause in Adam Smith', Contemporary Perspectives on Early Modern Philosophy, Dordrecht: Springer, pp. 159-77.

Schwarze, Michelle A. \& Scott, John T. (2015) ‘Spontaneous Disorder in Adam Smith's Theory of Moral Sentiments: Resentment, Injustice, and the Appeal to Providence', The Journal of Politics, Vol. 77, no. 2, pp. 463-76.

Smith, Adam (1976a [1776]). An Inquiry into the Nature and Causes of the Wealth of Nations, eds. R.H. Campbell, A.S. Skinner \& W.B. Todd (Oxford: Oxford University Press).

Smith, Adam (1976b [1759]). The Theory of Moral Sentiments, eds. D.D. Raphael \& A.L. Macfie (Oxford: Oxford University Press).

Smith, Adam (1978). Lectures on Jurisprudence, eds. R.L. Meek, D.D. Raphael \& P.G. Stein (Oxford: Oxford University Press).

Smith, Adam (1980) [1795]. Essays on Philosophical Subjects, ed. W.P.D. Wightman, (Oxford: Oxford University Press). 
Thomson, Herbert. (1965) 'Adam Smith's Philosophy of Science', Quarterly Journal of Economics 79, pp. 212-233.

Vivenza, Gloria (2010). 'Justice as a Virtue - Justice as a Principle in Adam Smith's Thought.' Revista Empresa y Humanismo, Vol. XIII, 1/10: 297-332.

Witzum, Amos and Young, Jeffrey T. (2010). 'Utilitarianism and the role of Utility in Adam Smith', Centre for Socio-Economic Research, London Metropolitan University, Discussion Paper Series, CSER DP no: 15 (London: London Metropolitan University).

\section{Summary}

The recent rediscovery of Adam Smith by philosophers has led a debate about the place of religion in his moral philosophy. The debate about the extent to which Smith's philosophy depends on religious arguments is probably unresolvable, so in this paper I examine what Smith's writings on religion can tells us about his conception of philosophy. The paper examines the interrelation of religion and philosophical method in Smith's work and argues that he adopts a 'reality check' approach which seeks to prevent philosophical systems from over-reaching themselves.

Keywords: Adam Smith, Moral Sentiments, philosophy, religion

\section{Streszczenie}

\section{Adam Smith o filozofii i religii}

Niedawne ponowne odkrycie przez filozofów Adama Smitha stało się powodem debaty na temat miejsca, jakie $\mathrm{w}$ jego filozofii moralnej zajmuje religia. Sporu dotyczącego tego, w jakim stopniu filozofia Smitha opiera się na argumentach religijnych zapewne nie da się rozstrzygnąć, dlatego $\mathrm{w}$ niniejszym artykule ograniczam się do tego, co o koncepcji filozoficznej Smitha mówią jego prace poświęcone religii. Badam w nim związki pomiędzy religią a metodą filozoficzną i twierdzę, że dla Smitha sprawdzianem systemów filozoficznych jest konfrontacja z rzeczywistością, dzięki której mogą się one ustrzec przed wykroczeniem poza swe własne założenia.

Słowa kluczowe: Adam Smith, uczucia moralne, filozofia, religia 